Vol. 12, $n^{\circ} 2 \mid 2008$

Varia

\title{
Patrick Colquhoun, the Scottish Enlightenment and Police Reform in Glasgow in the Late Eighteenth Century
}

David G. Barrie

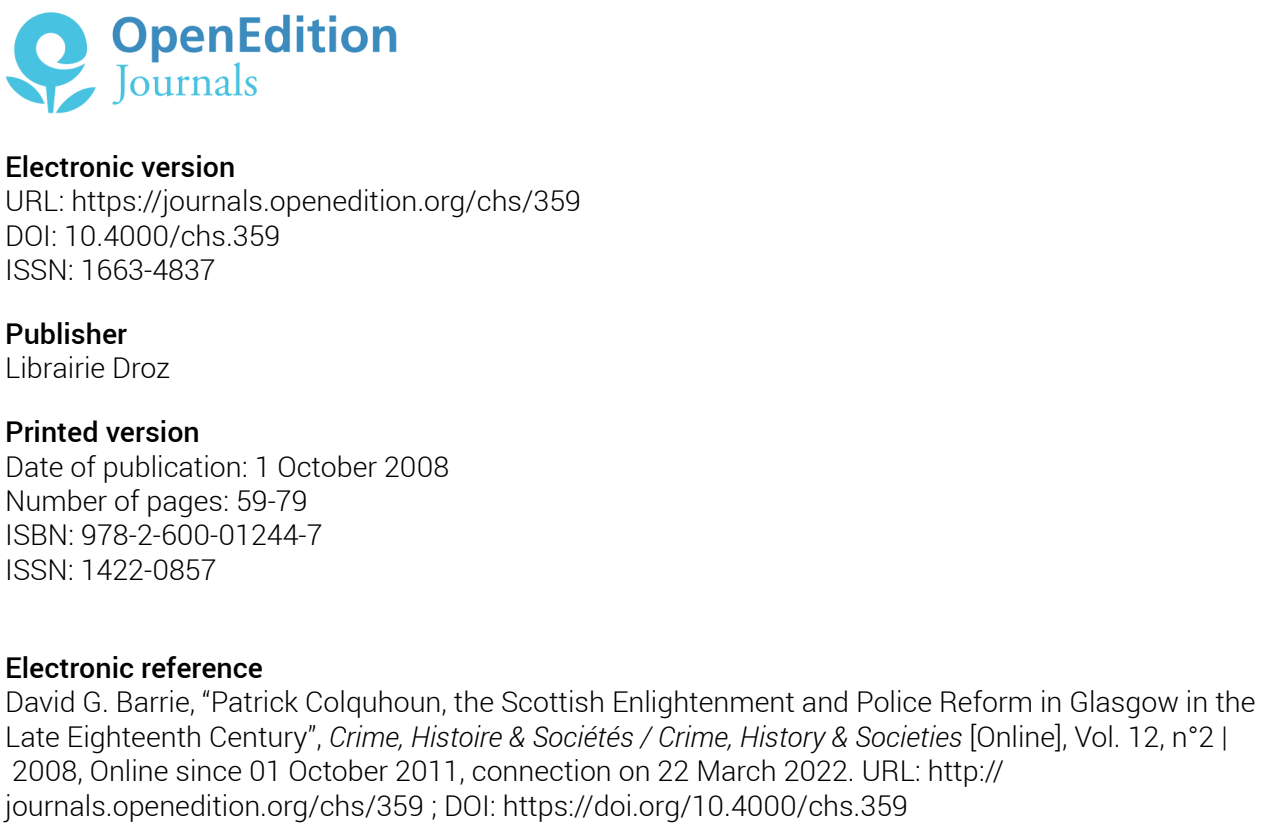

This text was automatically generated on 22 March 2022.

(c) Droz 


\section{Patrick Colquhoun, the Scottish Enlightenment and Police Reform in Glasgow in the Late Eighteenth Century $^{1}$}

David G. Barrie

\section{I - Introduction}

1 Patrick Colquhoun's (1745-1820) reputation for being a pioneer of police reform in London has been widely documented in older, institutional police histories. His monumental A Treatise on the Police of the Metropolis (1796) ${ }^{2}$ and work on the Thames River Police have seen him portrayed as the 'father of police science' and the 'architect of the 1829 Metropolitan Police Act' who 'government turned to for advice and direction's. His 'new science of policing', involving the prevention and detection of crime, has been accredited with laying the intellectual foundations for police reform in London. Moreover, he has been described as "the first major writer on public order and the machinery of justice to use "police" in a strict sense closely akin to modern usage's.

Others, however, view Colquhoun's contribution in a different light. It has been argued that his main impact on police reform was in calling for a 'social police' to discipline labour through the enforcement of a free-market, waged economy $y^{5}$. Others question whether he had much impact at all. Far from his ideas and writings shaping contemporary attitudes, Colquhoun has been portrayed as a marginal figure in public life. According to one source, he 'was a man of little or no significance in government circles' with the Home Office regarding him as little more than a crank ${ }^{6}$. It has been suggested that his role as architect of the 1829 Metropolitan Police Act was overstated with his proposed police model bearing little resemblance to the one which was later established ${ }^{7}$. 
While it is certainly the case that the traditional view overstates Colquhoun's role and importance, the revisionist viewpoint has gone too far in undermining his contribution'. It has become fashionable in recent years to underplay his significance, but this has to be viewed within the context of its time rather than seeking to relate it directly to reform in London in 1829. Colquhoun's lack of direct influence in government circles should not in itself undermine his impact. This transcended public life. Treatise on the Police of the Metropolis went through seven editions between 1796 and 1806 , while his books were widely and favourably received in local press reports and leading journals ${ }^{10}$. Indeed, his major contribution to policing is likely to have been in politicising the issue and stimulating a level of interest which previously it had not enjoyed. Moreover, he had a wider significance which has been largely overlooked by scholars concentrating on the issue of police reform. His works were important to the development of classical criminology - not least in locating the causes of crime in the overall structure of the economy and society ${ }^{11}$. He was, and remains, an important figure in criminal justice history, and one worthy of greater recognition and scholarly attention than some have given him.

4 It is not the intention of this article to re-visit the significance of Colquhoun's ideas or, indeed, to re-trace the origins of the Metropolitan Police Act. Both have been effectively explored elsewhere ${ }^{12}$. Rather, this paper seeks to examine from where Colquhoun's ideas on law enforcement were derived. The limited attention which has been given to this question has, among others, emphasised the role of police reformers John and Henry Fielding, penal reformers Jeremy Bentham and John Howard, and moral philosophers Hobbes, Beccaria and Mills ${ }^{13}$. A wide range of moral and religious influences have also been indentified ${ }^{14}$. It has even been suggested that the 1785 London Police Bill and developments in Ireland might have influenced Colquhoun's thinking ${ }^{15}$. It is certainly true that Colquhoun drew and built upon the ideas and works of others, from Sir John Fielding's criminal information network, to the French model of policing, which he believed had reached 'the greatest degree of perfection' ${ }^{16}$. However, it is argued in this paper that there was another dimension which has not received the attention it deserves. Underlying many of Colquhoun's ideas were developments in policing which were taking place in his native Glasgow in the late eighteenth century - ideas, which in turn, were influenced by the intellectual and philosophical revolution known as the Scottish Enlightenment ${ }^{17}$. In exploring this issue, the article will also examine the significant role played by the wider intellectual, commercial and political climate in shaping police reform in Scotland's largest city. In doing so, it hopes to broaden and deepen an historiography on police history which has focused a great deal on economic and social factors, but less on the context of ideas.

\section{II - Patrick Colquhoun and Police Reform in Glasgow}

Patrick Colquhoun was born in Dumbarton in 1745, the son of a magistrate and registrar of county records ${ }^{18}$. A successful linen merchant, he served as Lord Provost of Glasgow between 1782-3 and as a Lanarkshire Justice of the Peace for much of the 1780s. His great passion in his early years in public life was promoting and defending the interests of trade and commerce. In 1783, he founded and became the Chairman of the Glasgow Chamber of Commerce - the first in the United Kingdom. The Chamber transcended mercantile and craft divisions by bringing all businessmen in Glasgow 
together to pursue the common goal of developing commercial interests. Its establishment owed much not only to Colquhoun, but also to the vibrant and flourishing commercial centre that was Glasgow in the late eighteenth century. Nonetheless, Colquhoun has been widely acknowledged as the driving force behind the scheme $^{19}$. He also wrote extensively on the progress of manufacturing and business ${ }^{20}$. A prominent figure in civic life, the University of Glasgow in 1797 conferred upon him the degree of LL.D for his Treatise, and in 1800 he was given the freedom of Edinburgh.

6 However, it is Colquhoun's work on police in the metropolis for which he is most famous. In 1789, he moved to London to pursue his business interests. Within a few years, he was appointed one of the first stipendiary police magistrates in the city. A prolific writer on a number of subjects, it was Treatise on Police which caused the biggest stir and which cemented Colquhoun's reputation, in certain circles at least, as an important police reformer. In this landmark study, he called for the creation of a centralised police force to prevent and detect crime, as well as the establishment of a public prosecutor in order to relieve victims of the trouble and expense of prosecuting criminals. Ward constables were to maintain a 'general superintendence' of their districts, and there was to be a separation between police and judicial powers. 'Police' was interpreted widely, referring to many different branches, of which the criminal police was only part. Crime, he argued, was a product of indigence, ignorance and immorality, and needed to be tackled through the poor law and education as well as police reform. It was a structural consequence of the growth of commercial society, with increased wealth and changing social relations having a detrimental impact on the manners of the lower orders ${ }^{21}$.

7 Less well known is the role and influence Colquhoun's Scottish background had in shaping his thinking on policing. As with most other Scottish cities, Glasgow relied upon town officers and an unpaid watch of householders to police the streets in the late eighteenth century. Their roles were fairly modest. Neither was expected to be fulltime policemen. Town officers spent much of their time carrying out administrative duties relating to civil and criminal affairs. Although they had powers of arrest, these were largely derivative in the sense that they would act when called upon rather than patrol or police the streets on a regular basis in order to prevent crime ${ }^{22}$. Not surprisingly, the capacity for criminal investigation was extremely modest. Often, it was left to victims to investigate crime and pursue offenders themselves. The willingness of town officers to respond to reported offences was often dependent upon magisterial instruction, the nature of the offence committed and the likelihood of expenses being met $^{23}$. Similarly, watchmen were not designed to investigate and detect crime. In general, they would take action against criminals only if they were acting suspiciously or if offenders were caught in the act. The night watch's main role was to patrol the streets at night, apprehend or move on strangers who could not account for themselves, maintain a decent level of urban order, and protect property ${ }^{24}$.

8 Despite contemporary claims to the contrary, both town officers and night watchmen were fairly adequate for day-to-day law enforcement. In fact, the former continued to play an important role in enforcing the law after a permanent, full-time police force had been established in Glasgow in 1800 under a local police act. Neither, however, was suited to the emerging needs of a flourishing, rapidly expanding commercial centre. In the late eighteenth century, Glasgow was in the early stages of being transformed from a prosperous trading town into an international powerhouse of commerce and 
industry ${ }^{25}$. Growth in tobacco trading up to the 1770s, and an expansion in linen manufacturing thereafter, helped attract more and more migrants to the city, with the number of Glaswegians rising from 31,700 in 1755 to 77,000 in 1801. However, economic expansion came at a cost. There was, on several occasions, growing unease on the part of the emerging propertied classes towards the city's burgeoning manufacturing population and increasing social tension ${ }^{26}$. Crime and industrial unrest were reported to be on the increase. In 1793, Glasgow's contributor to the Statistical Account of Scotland noted that 'Great crimes were formerly very uncommon; but now robberies, housebreakings, swindling, pick-pockets, pilferers, and consequently executions... [have]... become more common ${ }^{27}$. By the late eighteenth century, the middle-ranks sought to place law enforcement arrangements on a more professional footing, which stimulated a campaign for a police act which lasted the best part of twenty years.

In 1779, magistrates experimented for a couple of years with employing an 'Inspector of Police' and some paid officers financed out of council funds ${ }^{28}$. The scheme coincided with mounting concerns with crime, vagrancy and anti-Catholic rioting in the city ${ }^{29}$, but underlying it was a growing recognition that a more professional system for investigating and detecting crime was necessary for such a large and prosperous city. As councillors argued, the appointment of an Inspector of Police was necessary due to

the multiplicity of business which falls under the magistrates department occasioned by the increase of the inhabitants of this city, and that by the close attendance and attention which the magistrates are obliged to give in hearing and determining pleas and disputes which are daily brought before them, and in managing the revenues of the city, it has of late years been found not only difficult to get respectable citizens to accept the office of magistracy, but also that those in that office cannot give that close attention to the police of the city for the detection of persons guilty of crimes and offences therein as is requisite ${ }^{30}$.

Interestingly, Colquhoun's proposed police in London were also to assume responsibility for some of the duties performed by magistrates.

The experiment ended after two years with the resignation of the 'Inspector of Police'. However, it was followed by a similar initiative a decade later and a lengthy campaign to acquire a police act with statutory tax-raising powers. In 1788, magistrates appointed an 'Intendent of Police', a Police Clerk and a number of 'police officers' ${ }^{31}$. The Intendent effectively assumed the role of Chief Constable and officers were organised by rank. The city was divided into nine districts, each with 'ward superintendents' - a concept which would re-surface in Colquhoun's Treatise.

In eighteenth-century England, there had been considerable innovation in terms of appointing salaried, professional, organised and uniformed law enforcement officers ${ }^{32}$. By eighteenth-century Scottish standards, however, the Glasgow initiative was innovative and forward thinking, seeking to prevent crime by introducing a degree of community supervision over local residents ${ }^{33}$. It was indicative, in many ways, of Colquhoun's notion of establishing a 'general superintendence' of local districts. Its underlying notion was that a successful scheme of police required locally appointed ward superintendents with intimate knowledge of suspicious characters and crimes ${ }^{34}$. More importantly, the Intendent was instructed 'to employ his officers in the evenings and during the night time in order to detect and prevent crimes $^{35}$. It has been suggested that this was the first time that the 'preventative policing' concept was formally written down ${ }^{36}$, although it is possible that similar instructions were enshrined in watchmen's and constables' regulations in other parts of the United 
Kingdom. Preventing crime had been a major concern of Henry Fielding in the mid eighteenth-century, and many watch forces patrolled dimly lit streets with the intention of doing this ${ }^{37}$. What is clear, however, is that Colquhoun's self-proclaimed 'new science of policing' was being discussed and debated at length in middle-rank circles in Glasgow several years before it made its appearance in Treatise. Indeed, in discussing a proposed police bill in 1789 , the Trades' House - which represented craft interests in the city - argued that the law enforcement clauses would prove ineffective as they were designed only 'for the detection and punishment of crimes once committed' and fall 'exceedingly short of that much more important object of preventing the increase, and removing the possible cause of the crimes ${ }^{38}$. Similar views were echoed in Edinburgh where Colquhoun was approached to provide advice on a local police bill ${ }^{39}$. In a speech to mark the appointment of the Superintendent of Police and the opening of the Police Court in 1805, the Lord Provost of Edinburgh employed language which was remarkably similar to the debates on policing in Glasgow in the 1780 s and 1790s and which was so eloquently espoused by Patrick Colquhoun in his Treatise on Police:

... much of the virtue of a nation depends upon the exertions of Police, in preventing crimes, in suppressing them in their infancy, and even in checking them in their advanced progress, especially in the Metropolis, which must always greatly influence, and I may say, even regulate the morals of the country, to which it belongs ${ }^{40}$.

13 Improving the morality of the lower orders by general police superintendence was an underlying theme behind the thinking of both Colquhoun and civic leaders in the large urban centres of Scotland as a whole. Clearly, the concept of 'preventative policing' was by no means as revolutionary as some have claimed.

Both policing initiatives in Glasgow in 1779 and 1788 exposed not only a growing intolerance of crime, but also the increasing problems of investigating and detecting it. The attitude of many local burgesses towards criminal investigation and the criminal justice system as a whole changed in the late eighteenth century. There was growing resentment that victims were expected to take the initiative in bringing legal action against offenders. New ways were sought to defend private property more effectively by making it easier to bring criminals to justice. As the Trades' House, in calling for the expenses of successful private prosecutions to be refunded in a proposed police bill in 1792, noted: 'Inhabitants have in past times been put frequently to great trouble and expense in searching for goods stolen from them and in bringing delinquents to punishment ${ }^{41}$. The difficulties local traders faced was highlighted in 1785 when two merchants in Port Glasgow unsuccessfully petitioned the Glasgow Chamber of Commerce requesting that financial assistance be given to victims intent upon pursuing a criminal case against suspects ${ }^{42}$. The appointment of full-time, salaried police officers was, in part, designed to relieve victims of property offences of some of the burden in pursuing offenders. So, too, was the appointment of a Police Clerk, whose duties were to include conducting criminal processes and preparing declarations and precognitions (witness testimonies) in criminal matters ${ }^{43}$. Although Scotland, unlike England, had a public prosecutor, legal redress was often the last course of action taken $^{44}$. It was widely reported that magistrates rarely brought criminals to court so as not to burden the burgh with legal $\operatorname{costs}^{45}$ (as the Crown would only reimburse expenses of cases tried in high courts or sheriff courts before a jury $)^{46}$. Fiscal constraints went a long way in ensuring that local magistrates, sheriffs and judges 
adopted an informal, pragmatic and cost-efficient approach to administering justice, with non-custodial punishments and informal sanctions, such as whipping, banishment and public humiliation, often being preferred to formal legal action ${ }^{47}$. Such a system, however, was increasingly criticised by men of property as being ineffective in an increasingly commercial society. The Trades' House, for instance, argued in 1792 that new ways were needed to ensure that more public resources would be made available to prosecute offenders to ensure that 'delinquents [would] ... be brought to justice upon the public expense ${ }^{48}$. Interestingly, Colquhoun advanced similar criticisms in calling for an effective system of public prosecution in England.

Both policing initiatives were financed from the council's limited funds and were shortterm solutions. What was needed in order to put policing arrangements on a more professional footing was a local police act with statutory tax-raising powers. The first attempt to introduce a police bill was made in 1783 when Colquhoun was Lord Provost of Glasgow, although how much influence he had over it is impossible to say ${ }^{49}$. The proposal which was drawn up was indicative of Colquhoun's notion of a 'municipal police'. In Treatise, hedefined 'police' broadly, writing about a 'general police' and different branches of local government. A police force, in other words, was part only of a wider municipal machine ${ }^{50}$. This was influenced, to a large degree, by the European meaning of 'police' as a form of urban administration for the common good ${ }^{51}$. Having said that, this broad notion of 'police' was in much more common use in eighteenthcentury urban Scotland than it was in other parts of the British Isles and Colquhoun's Scottish background is likely to have had a bearing on his thinking. The 1783 bill, for instance, sought wide-ranging police powers for lighting, paving, cleansing and watching. The intention was to improve policing arrangements, regulate public services and oversee a wide range of improvements. Although Glasgow relied upon the amateur system of 'watching and warding', there was a growing reluctance among men of property to give up their free time to perform their communal duty. According to one contemporary, John Strang, Glasgow City Chamberlain, the practice of hiring substitutes was so common that 'a large part of the guard very soon came to consist of these substitutes, permanently employed ${ }^{52}$. Indeed, in 1790 , the Faculty of Physicians and Surgeons and the members of the Faculty of Writers in Glasgow sought legal exemption from 'watching and warding' in the Court of Session in Edinburgh ${ }^{53}$. At the same time, civic pride, commercial incentive and raised expectations of comfort and security had stimulated growing interest in improving the urban environment, as modernisation and civic embellishment increasingly became important facets of urban development ${ }^{54}$.

The bill, however, was never formally presented to Parliament after meeting resistance from the Merchants' House and the Trades' House, both of whom feared that the extended municipal district would undermine trading privileges ${ }^{55}$. A few years later, however, magistrates drew up another police bill following widespread industrial militancy and growing concern with crime and unrest in the city. Although there were mounting demands for more effective protection for private property, a serious recession in the linen industry provided the catalyst for reform ${ }^{56}$. In 1787, 7,000 weavers went on strike in opposition to falling wage levels and fears about the dilution of their craft following the influx of a large number of unskilled workers. The strike illustrated that traditional employment patterns were eroding and that industrial relations were becoming more confrontational as productivity began to be organised more along capitalist lines in order to cater for a wider market ${ }^{57}$. The violent 
confrontation which ensued highlighted that the expanding industrial workforce was willing to resort to violent means in order to defend long-standing working practices, while at the same time exposing the limitations of existing policing arrangements ${ }^{58}$. The military had to be deployed to maintain order. In certain circles, riot was no longer perceived as a legitimate form of community protest against the infringement of traditional customs; it was rather a sectional, self-interested expression of violence which posed a serious threat to private property ${ }^{59}$.

Once again, however, magisterial attempts to acquire a police bill were thwarted. Although there was an emerging consensus in support of acquiring police powers ${ }^{60}$, men of property could not agree upon which model this should take. The majority of the middle ranks were not prepared to concede further financial control and responsibility to an unpopular and unaccountable municipal authority as the council's bills proposed, especially in the hostile political climate. They bitterly opposed council control being vested in a self-appointed group of colonial traders ${ }^{61}$. As Glasgow's economic fortunes became increasingly dependent upon manufacturing rather than trading following the end of the American Revolutionary Wars ${ }^{62}$, the city's manufacturers grew increasingly resentful that council affairs were vested in a small, unaccountable oligarchy of colonial traders. Like Colquhoun in Treatise, they advocated separating police and judicial powers; but, unlike Colquhoun, they wanted police affairs vested in a body of elected police commissioners, independent from magisterial control, under whom elected ward superintendents would serve. In calling for this, Glaswegians looked enviously towards Edinburgh where a similar model had been in existence since $1771^{63}$. Aside from the hostile political climate, the desire for the establishment of a 'rate-payer democracy' was embedded in Enlightenment notions of Scottish 'civil society'. This stressed that liberty under the rule of law could be assured only by allowing men of property to participate in public life ${ }^{64}$. In Essay on the History of Civil Society (1767), Adam Ferguson argued that allowing men of property to engage in public life - either through local government, voluntary initiatives or public debate was an essential ingredient of political liberty and the development of civil society ${ }^{65}$. Separation of government through public vigour and local action was not only an essential check to despotic rule, but also an important way in which men of property could fulfil their political aspirations and interact with public officials. Magistrates, on the other hand, were reluctant to establish an elected police board which could rival their own position and status. As a result, both magistrates and heritors and burgesses of the city eagerly sought control of policing affairs, both promoting their own proposals while bitterly opposing other plans ${ }^{66}$.

This produced a political stalemate lasting over ten years before a police act was finally acquired with compromise on both sides ${ }^{67}$. In 1800 , the Glasgow police commission was established to administer criminal and civil affairs in the city. It was similar, in many respects, to the improvement commissions which had been established in English towns from the mid eighteenth century, although the model was more democratically based and the range of powers more wide-ranging ${ }^{68}$. The board was to consist of twenty-four elected commissioners, chosen by $£ 10$ ratepayers and from among $£ 15$ householders. Ex officio places were reserved for the Lord Provost, three bailies, the Dean of Guild and Deacon Convenor, ensuring that there was not a complete separation between police and judicial powers. Magisterial authority relating to criminal jurisdiction remained unimpaired - they retained the right to arrest criminals and never ceded responsibility for preserving law and order. Nonetheless, the balance of 
power on the police board was firmly in the hands of elected representatives who were responsible for administering the powers conferred under the terms of the 1800 Glasgow Police Act. Described as an 'epoch-making statute' ${ }^{69}$, the act helped establish a new range of essential services and introduced a degree of community control over the election of representatives. It also provided a model for other burghs to follow and heralded an unprecedented period of police innovation across urban Scotland ${ }^{70}$. A day police and night watch force, under the control of commissioners, was established, consisting of a Master of Police, two sergeants, five police officers and sixty-three watchmen for a population in and around the city of 77,385. The continuing reference to 'watch force' highlighted the links with the past, but the appointment of 'police officers' under a disciplined, hierarchical command structure for the 'prevention and detection of crime' also forged important links with the future and should not be understated.

\section{III - The Influence of Patrick Colquhoun}

What role Colquhoun played in influencing policing developments in Glasgow is far from certain. From his time as Chairman of the Chamber of Commerce in the early 1780s, Colquhoun was concerned with the detrimental impact dockland crime was having on mercantile interests. His role as Chairman convinced him of the need to more effectively safeguard the interests of private property, trade and commerce. In 1783, he was at the forefront in pioneering a nationwide campaign to tackle tobacco smuggling which was reported to be inflicting 'great injury' on local merchants ${ }^{71}$. Following a representation made to him by local businessmen, he promoted an association among importers and manufacturers of tobacco 'for the purpose of suppressing and discouraging smuggling' in which they 'resolve, both collectively and individually to do their utmost to detect and expose all such illicit practices ${ }^{72}$. The Chamber argued that the best defence against smuggling would be a reduction on tobacco duties ${ }^{73}$, but it is unlikely to be a coincidence that in the same year the first attempt was made to acquire a police bill and paid watch amidst growing concerns with property offences. Moreover, as serving Lord Provost, Colquhoun is likely to have been instrumental in the ensuing discussions. Similarly, he was a serving councillor when the small police force was set up in 1788 .

Interestingly, however, Colquhoun was not one of the six members of the council committee which devised the 1788 police scheme. Moreover, he moved to London in 1789, just as the political dialogue on policing in Glasgow was about to intensify. Although he continued to be widely respected in civic circles, and continued to take a keen interest in developments in the city ${ }^{74}$, his impact on the political discourse surrounding policing is likely to have been greatly reduced from this point onwards. The publication of his Treatise in 1796 appears to have had less impact in his native city than it did in London; it coincided, for instance, with a lull in calls for police reform in Glasgow - calls which did not re-surface until a serious recession in 1799 stimulated concerns with crime, disorder and the urban poor. Indeed, the 1800 Glasgow Police Act was similar in many ways to the local police bills which had been advanced before Colquhoun had published his famous study.

21 Far from Colquhoun influencing reform in Glasgow, it has been suggested that developments in his native city - and, in particular, the 'preventative policing' 
experiment which was launched in 1788 - influenced his subsequent work on the police of the metropolis ${ }^{75}$. As a councillor and senior magistrate, Colquhoun would have experienced at first hand the debates surrounding police reform, but the extent to which this influenced his thinking in Treatise needs to be viewed critically. After all, many of the key principles in Treatise, such as the separation between judicial and police powers in the form of a central rather than local board of police, were far removed from the proposals which were advanced in Glasgow. Moreover, Colquhoun drew comparisons between law enforcement arrangements in London, Dublin and France, but not, significantly, Glasgow ${ }^{76}$. Indeed, his inspiration owed much to policing arrangements in $\mathrm{France}^{77}$. His ideas are also, to some extent, likely to have been conditioned by his experiences as a serving magistrate in London in the 1790s rather than being simply imported from developments in Glasgow up to a decade earlier.

Equally, however, there is evidence to suggest that Colquhoun's Scottish background was a source of inspiration. As was outlined above, a number of his ideas bore a striking resemblance to the political discourse surrounding police reform in Glasgow in the late eighteenth century. Colquhoun came from a background that was questioning the existing system of criminal investigation and prosecution, and looking at new ways to better protect private property. It was an intellectually innovative climate that is likely to have made a significant impression on him. Moreover, his efforts to improve dockland security at Scottish ports mirrored his later work in London. In 1797, he was asked by a group of leading London West India merchants - in itself significant in highlighting the degree of standing he held in both commercial and law enforcement circles - to establish a private river police funded by dock owners. In 1800, the same year Colquhoun published A Treatise on the Commerce and Police of the River Thames, the private police force was converted under statutory authority into the Thames River Police $^{78}$. As the time he spent as Chairman of the Chamber of Commerce highlighted, his interest in safeguarding trading interests had their intellectual origins in Glasgow.

Colquhoun's inspiration, however, went beyond developments in his native city. Underlying Treatise were ideas and values which were shaping many facets of Scottish society in the eighteenth century, not just attitudes towards police, prosecution and commerce. It was from the fertile intellectual climate of the Scottish Enlightenment that much of Colquhoun's ideas and inspiration would be derived.

\section{IV - Law, Property, Improvement, and the Scottish Enlightenment ${ }^{79}$}

Unlike Colquhoun, the leading figures of the Scottish Enlightenment did not advocate introducing professional police forces. Like many of their English counterparts, there was a general feeling that the most effective defence against crime and disorder was unlikely to be ensured by an extended, centralised policing system designed to interfere with individual liberty. Adam Smith, for instance, noted that 'we shall only observe ... that those cities where the greatest police is exercised are not those which enjoy the greatest security ${ }^{80}$. He argued that a more effective way to ensure security was through the establishment of manufactures and commerce, and the liberty and prosperity which they brought:

Upon the whole it is the custom of having many retainers and dependents which is

the greatest source of all disorders and confusion in some cities; and we may also 
affirm that it is not so much the regulations of police which preserves the security of a nation as the custom of having in it as few servants and dependents as possible ${ }^{81}$.

25 'Police' as a 'body of men' drew little attention. Intellectual debates on defence and security were often closely linked with demands for a Scottish militia rather than dayto-day law enforcement ${ }^{82}$. Indeed, according to Smith, the role of the night guard was 'a subject too mean and too minute for our consideration ${ }^{83}$.

However, while not debating the issue of 'policing' per se, the rule of law, and how it could be best enforced and administered, was a burning issue for Scottish Enlightenment thinkers. Like the middle ranks in Glasgow, the Scottish literati were largely preoccupied with protecting commerce and property - issues which were close to Colquhoun's heart from his time spent establishing and championing the cause of the Chamber of Commerce. Among moral philosophers, Scots law and its relationship with the progress of society occupied a central place ${ }^{84}$. Particular attention was given to the process of legal development and its relationship with the economic organisation of society through time ${ }^{85}$. Lord Kames, David Hume and Adam Smith all recognised the economic and social context in which laws operated ${ }^{86}$. They argued that in an increasingly commercial society it was the duty of government to create new laws to protect private property. Lord Kames, for instance, argued that 'It is ... a principle of the law of nature, and essential to the well-being of society that men be secured in their possessions honestly acquired ${ }^{87}$.

Significantly, Kames, Hume and Smith recognised that it was not enough simply to introduce new laws to protect property, preserve social order and promote commerce. New ways of enforcing them also had to be found in order to secure the rule of law. For Kames, the criminal law in Scotland had to be reformed in accordance with the changing needs of a commercial society, which included developing a system of public administration capable of dealing with, and punishing, relatively minor offences, and which would protect property and society as a whole rather than one geared simply towards retribution ${ }^{88}$.

It was essential, argued Hume, for men of property to form governments, not just out of common interest, but as a form of collective security motivated out of self-interest. In Treatise of Human Nature (1739), he contended that it if society was to progress, civil government had to provide protection and justice through its authority ${ }^{89}$. Similarly, Smith - drawing on Montesquieu's 'four stages' of human development in Esprit des Lois - argued that societies which recognise private property and inequality require laws and regular systems of enforcement to safeguard the security of ownership ${ }^{90}$. In Wealth of Nations, he wrote that the acquisition of valuable and extensive property ... necessarily requires the establishment of civil government ${ }^{91}$. The interests of property and civil government were mutually dependent. He elaborated upon this in the Theory of Moral Sentiments: 'till there be property there can be no government, the very end of which is to secure wealth and defend the rich from the poor ${ }^{92}$. In a commercial society, therefore, it was essential for governments and laws to evolve to defend property and social order ${ }^{93}$. In calling for a stronger magistracy and coercive form of law enforcement, Smith argued that:

It is only under the shelter of the civil magistrate that the owner of that valuable property, which is acquired by the labour of many years, or perhaps of many successive generations, can sleep a single night in security ${ }^{94}$. 


\section{would be profound:}

As the violation of justice is what men will never submit to from one another, the public magistrate is under the necessity of employing the power of the commonwealth to enforce the practice of this virtue. Without this precaution, civil society would become a scene of bloodshed and disorder, every man revenging himself at his own hand whenever he fancied he was injured ${ }^{95}$.

Kames, Hume and Smith, by implication, were calling for improved forms of protection and law enforcement. They had considerable social standing and influence within the Scottish public sphere. Their views were widely accepted and diffused among Glasgow's commercial professional ranks. A significant proportion of the city's business leaders were schooled at the University of Glasgow, whose scholars - Smith included - were at the forefront of the Scottish Enlightenment ${ }^{96}$. Colquhoun was not immune from this intellectual context. His Scottish background permeates many of his works, not just on police, but also his other great passion, commerce. Throughout his years spent in public life, Colquhoun was concerned primarily with the progress of civil society, the common good and safeguarding property. In Treatise, he mirrored Hume, Smith and others by emphasising the need for laws, and the judicial system as a whole, to be reformed in order to prevent crime and, above all, protect property: 'It is by the general influence of good laws and regulations, that the blessings of true liberty and the undisturbed enjoyment of property is preserved, as far as legislative authority can prove a security against iniquity and depredation ${ }^{97}$. Embedded in Colquhoun's works was the ideal of civil society which became common in British political discourse in the late eighteenth century ${ }^{98}$. At times an ambiguous concept, Hume and Smith argued that the defining characteristic of civil society was the emergence of formal governing and law-enforcing institutions of which 'good police' was one ${ }^{99}$. Developed in civic terms by the Scottish philosopher Adam Ferguson, this ideal stressed that it was incumbent upon the propertied ranks to create a better and more civilised society by becoming involved in public life $\mathrm{f}^{100}$. Colquhoun mirrored this in calling for men of property to show active vigour in improving the police of the metropolis. Although emerging out of growing concern, Treatise was fundamentally an imaginative historical work on what could be achieved by public spirit, energy and vigour. At its core was the notion that individuals were able to shape and improve their environment to a far greater degree than ever before, which was in embedded in Enlightenment notions of 'civic humanism' and the 'civic duty'.

Moreover, there is evidence to suggest that Colquhoun was influenced to some degree by Adam Smith, who he visited on a number of occasions in London ${ }^{101}$. Like Smith, Colquhoun and his mercantile counterparts in Glasgow were vociferous advocates of free trade. In 1814, Colquhoun produced a statistical analysis of Britain's resources in A Treatise on the Population, Wealth, Power and Resources of the British Empire, in which his economic theories for the control of crime, indigence and ignorance were largely borrowed from Smith. Although influenced also by Henry Fielding and Jonas Hanway ${ }^{102}$, Colquhoun's view that immorality had risen in line with commercial expansion was also in keeping with concerns expressed by Adam Smith. Both Colquhoun and Smith believed that commercial expansion had promoted a lack of respect for authority among many of the lower orders. There were, of course, important differences in how best to respond to this, with Colquhoun calling for a system of preventative police and Smith extensive educational provision, but both shared the view that the manners of 
the lower orders had to be controlled and regulated for the public good ${ }^{103}$. Moreover, like his widely acclaimed counterpart, Colquhoun also saw benefits arising from the division of labour in maintaining law and order ${ }^{104}$. Although, in principle, a supporter of the militia, Smith recognised that in commercial society manufacturers and producers were less likely give up their time for voluntary military service which made some form of functional specialisation - akin to a standing army - necessary ${ }^{105}$. In Treatise, Colquhoun advocated the introduction 'of an active agency in the persons of an intelligent and zealous Magistracy, pervading every part of the metropolis, and dividing the labour in such a manner as to give full scope to the different talents and powers of those destined to put laws in execution ${ }^{106}$. He also argued that employing substitutes could have benefits as they were more likely to show vigour in the exercise of their duties than unpaid householders ${ }^{107}$. Furthermore, although Colquhoun used the word 'police' in its modern sense by referring to forces of men to prevent and detect crime, his emphasis on a 'General Police' was remarkably similar to how the concept was applied in late eighteenthcentury Scotland at a time, crucially, when it was beginning to take on a more specialist association with law and order in other parts of the United Kingdom ${ }^{108}$. In Lectures in Jurisprudence, for instance, Smith referred to 'police' as

the second general division of jurisprudence ... which properly signified the policy of civil government, but now means the regulation of inferior parts of government, viz.: cleanliness, security, and cheapness or plenty ${ }^{109}$.

Colquhoun, of course, helped develop the notion of 'police' as a form of law enforcement by insisting that the branch of police for preventing and detecting crime should be separate from the judiciary ${ }^{110}$. Unlike most other leading figures of the Scottish Enlightenment, he argued that a strong and vigorous police was as important to the progress of society as the law. Tracing Colquhoun's ideas directly to the Kames, Hume and Smith and others would ignore the contribution Colquhoun himself made to evolving ideas on law enforcement, as well overlooking some of the significant ways that his ideas differed from his more illustrious Scottish intellectual counterparts. Equally, however, there were many similarities. Colquhoun was, in many respects a product, and largely overlooked figure, of the Scottish Enlightenment. Many of his ideas, like those of Edwin Chadwick and other police reformers, were inspired by the intellectual currents which flowed from Enlightenment thought. They were extremely important in familiarising the educated public with a new paradigm, even if those in government circles were initially unresponsive. This is indicative of the important role the wider context of ideas played in the evolution of modern policing.

Moreover, in so far as Colquhoun's thoughts on police in the metropolis influenced contemporary thinking in London, it is possible that the periphery shaped the centre to some degree. Recent research has shown that developments in Ireland in the late eighteenth and early nineteenth centuries helped mould the police model which was established in London in $1829^{111}$. Scotland might also have had an important role to play, although not so much in terms of the model which was to evolve in England, but rather in the intellectual and philosophical discourse which emanated from the Scottish Enlightenment. 


\section{V - Conclusion}

35 New thinking on law enforcement in Glasgow in the late eighteenth century had its origins in the city's complex intellectual, demographic, commercial and political milieu. Although there were short-term catalysts, such as the industrial militancy of the late 1780s, attempts to reform the city's policing arrangements were closely linked with growing demands for more effective protection for private property, closer investigation of crime and greater certainty of prosecution. A more professional approach to policing and the administration of justice was being sought which was in keeping with the emerging needs of a commercial society. By the late eighteenth century, there was a growing recognition that the administration and enforcement of law and order would have to be reformed in line with commercial expansion and the increased ownership of property.

It would be easy to view Colquhoun as being a mouthpiece for the propertied elite someone who articulated and promoted middle-rank concerns that had been thrownup by the changing intellectual, economic and social climate. In many ways, he was. His time spent serving in the Chamber of Commerce was largely devoted to protecting and safeguarding commercial interests, while he is likely to have played a part in many of the early efforts to improve law enforcement arrangements both in the docks and within the city itself.

However, to view Colquhoun as being merely a middle-rank figure-head takes insufficient account of the complex economic and political divisions within the city. Men of property were far from united. While the majority were in favour of police reform to improve order, protect property and relieve them of the burden of watching and warding, there were divisions and disagreements over what model this should be. Unfortunately, there is little documentary evidence outlining Colquhoun's views on this for Glasgow. However, given his council connections, these are likely to have mirrored those of others in civic circles - namely, that policing arrangements should be under the authority of magistrates. This is unlikely to have won Colquhoun many friends among the overwhelming majority of the propertied ranks, who favoured police control being vested in a directly elected police commission. Significantly, there is no indication, at this stage, of a central policing model being proposed for Glasgow - a model which Colquhoun was later to advance for London. Indeed, it is interesting to note just how little attention educated opinion in Glasgow appears to have given to developments in London. Neither the appointment of police officers in London under the control of full-time, paid magistrates in 1792 (of which Colquhoun was one) nor Colquhoun's Treatise in 1796 was recorded in the municipal records in Glasgow. Moreover, neither of these appears to have influenced discussions in any significant shape or form. Efforts to introduce similar schemes in Glasgow would have been strongly resisted for reasons outlined above. Glaswegians were more likely to look towards Edinburgh rather than London when discussing policing models, which was indicative of a thriving provincial rather than metropolitan culture ${ }^{112}$.

Moreover, the police model which was established in the city - with its wide-ranging municipal powers - was rooted in Enlightenment notions of improvement for the common good. It was not perceived simply as being a class tool to ensure the defence of property and inequality in society. While safeguarding middle-rank interests was of paramount concern to reformers, the thirst for policing powers was also indicative of 
an intellectual and philosophical move in favour of a more orderly, structured and better behaved society. It was from this intellectually stimulating climate that Colquhoun and police reformers in his native city would draw inspiration.

\section{BIBLIOGRAPHY}

Avery, M.E., Patrick Colquhoun (1745-1820): "a being clothed with divinity", Journal of police history society, 1988, 3, p. 24-34.

Barrie, D. G., Britain's oldest police? A political and social history of policing in Glasgow, 1779-1846, Ph.D thesis, University of Strathclyde, 2001.

Barrie, D. G., Police in the age of improvement: police development and the civic tradition in Scotland, 1775-1865, Devon, Willan Publishing, 2008.

Beattie, J.M., Policing and punishment in London, 1660-1750, Oxford, Oxford University Press, 2001.

Bell, J., Paton, J., Glasgow: its municipal organisation and administration, Glasgow, James MacLehose and Sons, 1896.

Cairns, J. W., "Famous as a school for law, as Edinburgh... for medicine": legal education in Glasgow, 1761-1801, in Hook, A., Sher, R. B. (eds), The Glasgow Enlightenment, East Linton, Tuckwell Press, 1995, pp. 133-159.

Colquhoun, P., Heads of a plan for establishing a chamber of commerce and manufactures in the city of Glasgow and the places adjacent, Glasgow, Publisher Unknown, 1782.

Colquhoun, P., Considerations relative to a plan of relief for the cotton manufactory, London, Publisher Unknown, 1788.

Colquhoun, P., A representation of facts relative to the rise and progress of cotton manufacture in Great Britain, London, Publisher Unknown, 1789.

Colquhoun, P., A treatise on the police of the metropolis, explaining the various crimes and misdemeanours which at present are felt as a pressure upon the community; and suggesting remedies for their prevention, London, H. Fry, 1796.

Colquhoun, P., A treatise on the commerce and police of the river Thames, London, H. Baldwin and Sons, 1800 .

Colquhoun, P., A treatise on the population, wealth, power and resources of the British Empire, London, J. Mawman, 1814.

Critchley, T.A., A history of police in England and Wales 900-1966, London, Constable, 1967.

Crowther, A., Crime, prosecution and mercy: English influence and Scottish practice in the early nineteenth century, in Connolly, S.J. (ed.), Kingdoms united? Great Britain and Ireland since 1500: integration and diversity, Dublin, Four Courts, 1999, pp. 225-238.

Devine, T.M., The tobacco lords, Edinburgh, John Donald, 1975.

Dinsmor, A., Glasgow police pioneers, Journal of the police history society, number 15, 2000, pp. 9-11. 
Dodsworth, F., Police and the prevention of crime: commerce, temptation and the corruption of the body politic, from Fielding to Colquhoun', The British Journal of Criminology, 2007, 47, 3, pp. 439-454.

Emsley, C., The English police: a political and social history, second edition, London, Longman, 1996. Emsley, C., The birth and development of the police, in Newman, T. (ed.), Handbook of policing, Devon, Willan Publishing, 2003, pp. 66-83.

Eyre-Todd, G., History of Glasgow, volume III: from revolution to the passing of the reform acts, 1832-3, Glasgow, MacLehose, Jackson and Co., 1934.

Ferguson, A., Essay on the history of civil society, Edinburgh, Bell and Bradfute, 1767.

Fraser, D., Urban politics in Victorian England. The structure of politics in Victorian cities, Leicester, Leicester University Press, 1976.

Fraser, W.H., Conflict and class: Scottish workers, 1700-1838, Edinburgh, John Donald, 1988a.

Fraser, W.H., Patterns of protest, in Devine, T.M., Mitchison, R. (eds), People and society in Scotland, volume I, 1760-1830, Edinburgh, John Donald, 1988b, pp. 268-291.

Harris, A. T., Policing the city: crime and legal authority in London, 1780-1840, Columbus, Ohio State University Press, 2004.

Harris, B., Towns, improvement and cultural change in Georgian Scotland: the evidence of the Angus burghs, c.1760-1820, Urban history, 2006, 33, 2, pp. 195-212.

Harris, J., From Richard Hooker to Harold Laski: changing perceptions of civil society in British political thought, late sixteenth to early twentieth centuries, in Harris, J. (ed.), Civil society in British history: ideas, identities, institutions, Oxford, Oxford University Press, 2003, pp. 13-38.

Hay, D., Property, authority and the criminal law, in Hay, D., Linebaugh, P., Thompson, E. P. et al., Albion's fatal tree: crime and society in eighteenth-century England, London, Allen Lane: Panthen Books, 1975,pp. 17-64.

Herman, A., The Scottish enlightenment: the Scots' invention of the modern world, London, Fourth Estate, 2002.

Hume, D., A treatise of human nature, London, Publisher Unknown, 1739 (ed.), Ernest C. Mossner, Harmondsworth, Penguin Books, 1969.

Jackson, G., Glasgow in transition, c.1690-c.1740, in Devine, T.M., Jackson, G. (eds), Glasgow, volume I: beginnings to 1830, Manchester, Manchester University Press, 1995, pp. 214-238.

Kames, Lord, History of criminal law, The historical law tracts, Edinburgh, Bell and Bradfute and W. Creech, 1758, pp. 72-75.

Kilday, A.-M., Women and violent crime in enlightenment Scotland, Suffolk, Royal Historical Society/ Boydell Press, 2007.

King, P., Crime, justice and discretion in England, 1720-1820, Oxford, Oxford University Press, 2000.

Langbein, J. H., Albion's fatal laws, Past and present, 1983, 98, pp. 96-120.

Langford, P., Public life and the propertied Englishman 1689-1798, Oxford, Clarendon Press, 1991.

Lenman, B., Parker, G., Crime and control in Scotland 1500-1800', Today, 1980, 30, January, pp. 13-17. 
Lieberman, D., The legal needs of a commercial society: the jurisprudence of Lord Kames, in Holt, I., Ignatieff, M. (eds), Wealth and virtue: the shaping of political economy in the Scottish enlightenment, Cambridge, Cambridge University Press, 1983, pp. 203-234.

MacCormick, N., Law and enlightenment, in Campbell, R.H., Skinner, Andrew S. (eds), The origins and nature of the Scottish enlightenment, Edinburgh, John Donald, 1982, pp. 150-166.

MacCormick, N., Adam Smith on law, in Haakonssen, K. (ed.), Adam Smith, Aldershot, Ashgate, 1998, pp. 189-210.

Maver, I.E., The guardianship of the community: civic authority before 1833, in Devine, T.M., Jackson, G. (eds), Glasgow, volume I: beginnings to 1830, Manchester, Manchester University Press, 1995, pp. 239-277.

Maver, I., Glasgow, Edinburgh, Edinburgh University Press, 2000.

Meek, R.L., Raphael, D.D., Stein, P.G. (eds), Adam Smith: lectures on jurisprudence, Oxford, Clarendon Press, 1978 edition.

Meikle, H.W., Scotland and the French revolution, second edition, London, Frank Cass, 1969.

Melville Lee, W.L., A history of police in England, London, Methuen, 1901.

Morris, R.J., Civil society and the nature of urbanism: Britain, 1750-1850, Urban history, 1998, 25, 3, pp. 287-301.

Neocleous, M., Social police and the mechanisms of prevention. Patrick Colquhoun and the condition of poverty, British journal of criminology, 2000, 40, pp. 710-726.

Paley, R., “An imperfect, inadequate and wretched system?” Policing London before Peel, Criminal justice history, 1989, 10, pp. 95-130.

Palmer, S.H., Police and protest in England and Ireland, 1780-1850, Cambridge, Cambridge University Press, 1988.

Philips, D., Storch, R. D., Policing provincial England, 1829-56: the politics of reform, London, Leicester University Press, 1999.

Radzinowicz, L., A history of English criminal law and its administration from 1750, volume 3: cross-currents in the movement for the reform of the police, London, Stevens, 1956.

Rawlings, P., Policing: a short history, Devon, Willan Publishing, 2002.

Reiner, R., British criminology and the state, The British journal of criminology, Spring, 1988, 28, 2, pp. 138-158.

Renwick, R., Extracts from the records of the burgh of Glasgow, volume VIII, 1781-95, Glasgow, Scottish Burgh Records Society, 1913.

Reynolds, E. A., Before the bobbies: the night watch and police reform in metropolitan London, 1720-1830, Stanford, Stanford University Press, 1998.

Robertson, J., The Scottish enlightenment at the limits of the civic tradition, in Holt, I., Ignatieff, M. (eds), Wealth and virtue: the shaping of political economy in the Scottish enlightenment, Cambridge, Cambridge University Press, 1983, pp. 137-178.

Robertson, J., The Scottish enlightenment and the militia issue, Edinburgh, John Donald, 1985.

Skinner, A., Adam Smith: society and government, in Attwooll, E. (ed.), Perspectives in jurisprudence, Glasgow, University of Glasgow Press, 1977, pp. 195-220.

Smith, A., The theory of moral sentiments, London, A. Millar, 1761. 
Smith, A., Lectures on justice, police, revenue and arms, delivered in the university of Glasgow by Adam Smith, reported by a student in 1763, Glasgow, first published in 1776, edited by Cannan, E., London, 1896.

Styles, J., The emergence of police - explaining police reform in eighteenth- and nineteenthcentury England, in Newman, T. (ed.), Policing: key readings, Devon, 2005, pp. 80-87.

Webb, S., Webb, B., The development of English local government, 1689-1835, London, Oxford University Press, 1963.

Whatley, C. A., Labour in the Industrialising City, c.1660-1830, in Devine, T.M., Jackson, G. (eds), Glasgow, volume I: beginnings to 1830, Manchester, Manchester University Press, 1995, pp. 360-402. Williams, A., The police of Paris, 1718-1789, London, Baton Rouge, 1979.

Yeats, G.D., A bibliographical sketch of the life and writings of Patrick Colquhoun by Iatros, London, G. Smeeton, 1818.

\section{NOTES}

1. Thanks are owed to the Economic and Social Research Council for a small grant which helped fund the research for this article (RES-000-22-1758). The author is extremely grateful to the anonymous referees who provided advice on an earlier draft. The principal focus of the paper is on Patrick Colquhoun, as a central character in police history. However, for a broader argument, focusing more on the politics of reform in Glasgow, see David G. Barrie, Police in the age of improvement: police development and the civic tradition in Scotland, 1775-1865, Devon, Willan Publishing, 2008, Chapter 3.

2. Colquhoun (1796).

3. See, for instance, Radzinowicz (1956, Volume 3, p. 226); Melville Lee (1901, pp. 218-223); Critchley (1967, p. 38).

4. Radzinowicz (1956, Volume 3, p. 247).

5. Neocleous (2000, p. 724). For a critique of this, see Dodsworth (2007).

6. Paley (1989, p. 98).

7. Emsley (1996, p. 22). Colquhoun's role in developing the modern meaning of 'police' has also been questioned. According to one author, he was, at best, 'a transitional figure between older, broader views of policing and the narrower, more modern definitions'. See Reynolds (1998, p. 84).

8. Paley (1989).

9. Rawlings (2002, p. 113).

10. Radzinowicz (1956, Volume 3, p. 227).

11. Reiner (1988, p. 142).

12. For a good overview of Colquhoun's life and writings, see Radzinowicz (1956, Volume 3, pp. 211-312). For the origins of the 1829 Metropolitan Police Act, see Reynolds (1998); Harris (2004).

13. See, for instance, Reynolds (1998, p. 91); Melville Lee (1901, p. 218); Critchley (1967, p. 38).

14. Dodsworth (2007, p. 447).

15. Palmer (1988, p. 119).

16. Cited in Critchley (1967, p. 39).

17. The few studies which have emphasised the important role played by developments in Glasgow are Avery (1988); Dinsmor (2000, p. 9). However, although interesting, these are fairly short articles which ignore the intellectual context. 
18. Unless otherwise stated, the information in this paragraph has been derived from Yeats (London, 1818).

19. Eyre-Todd (1934, p. 321).

20. For his ideas on this, see Colquhoun (1782). See also Colquhoun $(1788,1789)$.

21. Dodsworth (2007, p. 441).

22. See, for instance, Perth and Kinross Council Archives (P.K.C.A.), Burgh court criminal processes, 1797, B59/26/21/1 bundle 5 .

23. Crowther (1999, pp. 225-226).

24. Beattie (2001, pp. 170-172).

25. For more on the city's economic expansion, see Whatley (1995); Maver (2000, pp. 16-34).

26. Whatley (1995, pp. 382-383).

27. The statistical account for Scotland, 1791-1799, volume VII, Lanarkshire and Renfrewshire (Wakefield, E. P. Publishing, 1973), p. 329.

28. G.C.A., 'Glasgow town council minute book', C1/1/36, 2 March 1779. The Inspector's appointment was initially for one year in order to establish the expediency of such an office, although James Buchanan served in this position until 5 April 1781. Magistrates and councillors decided on receiving Inspector Buchanan's resignation not to continue the office for the time coming. G.C.A., Glasgow town council minute book, C1/1/36, 5 April 1781.

29. Maver (1995, p. 249).

30. G.C.A., Glasgow town council minute book, C1/1/36, 2 March 1779.

31. Ibid., $\mathrm{C} 1 / 1 / 38,10$ December 1788.

32. Styles (2005).

33. Very few Scottish burghs in the late eighteenth century even employed paid watch forces. For more on this, see Barrie (2008, Chapter 2).

34. Information relating to this scheme in 1788 is revealed following discussions on a proposed police bill over a decade later. See G.C.A., T-TH1/1/8, Trades' house minutes, 15 October 1789.

35. G.C.A., C1/1/38, Glasgow town council minute book, 10 December 1788.

36. Dinsmor (2000, p. 10).

37. Beattie (2001, p. 67).

38. G.C.A., T-TH1/1/8, Trades' house minutes, 13 July 1789.

39. In 1804, Colquhoun received the thanks of magistrates in Leith and Edinburgh for remarks on a proposed scheme of police in these burghs. The following year, Edinburgh acquired its first police act. Leith acquired one in 1806. Edinburgh City Archives, (E.C.A.), SL80/1/5, Leith commissioners minute book, 30 May 1804.

40. Edinburgh Advertiser, 16 July 1805.

41. G.C.A., T-TH1/1/8, Trades' house minutes, 23 March 1792.

42. G.C.A., Glasgow Chamber of Commerce correspondence and other papers, TD1670/4/series, letter dated 8 July 1785.

43. G.C.A., Glasgow town council minute book, C1/1/38, 18 August 1790.

44. Lenman, Parker (1980, p. 15).

45. See, for instance, the Dundee, Perth and Cupar Advertiser, 29 December 1815 and 29 November 1816.

46. Crowther (1999, p. 234).

47. The Dundee lawburrow minute books between 1775 and 1799, for instance, have 221 banishments recorded, with the returns showing an increase up until the outbreak of the Napoleonic Wars. Dundee City Archives (D.C.A.), Lawburrows books of Dundee, 1775 to 1799 . No reference numbers.

48. In discussing a proposed police bill in 1792, the Trades' House called for the Intendent of Police to take cognisance of the investigation and detection of crime at the public's expense, provided that when stolen goods are recovered and criminals brought to justice, the owner 
should pay towards expenses a sum not exceeding five per cent of the goods' value. G.C.A., TTH1/1/8, Trades' house minutes, 23 March 1792.

49. G.C.A., C1/1/37, Glasgow town council minute book, 12 February 1783.

50. This is explored more fully in Reynolds (1998, pp. 89-90).

51. See, for instance, Williams (1979, pp. 8-9).

52. Eyre-Todd (1934, p. 339).

53. G.C.A., C2/1/1, Regulations for the city guard, 1790 , pp. 220-224. The outcome of this case was not found in the sessional papers.

54. Jackson (1995, pp. 85-88); Maver (2000, pp. 27-28); Harris (2006, p. 202).

55. G.C.A., T-TH1/1/8, Trades' house minutes, 3 March 1783. G.C.A., C1/1/37, Glasgow town council minute book, 12 April 1783.

56. For more on the strike, see Whatley (1995, p. 375); Fraser, (1988a, passim).

57. See Fraser (1988b, pp. 277-278).

58. Maver (2000, p. 29).

59. Fraser (1988b, pp. 272-281).

60. The struggle behind the 1800 Glasgow Police Act is explored more fully in Barrie (2001, pp. 174-178).

61. See Meikle (1969, p. 19).

62. Devine (1975, p. 166).

63. G.C.A., T-TH1/1/8, Trades house minutes, 5 April 1790.

64. Robertson (1983, p. 175).

65. Morris (1998, p. 291).

66. See, for example, Renwick (1913, pp. 93, 97, 288, 333, 341, 342, 348, 349, 355, 356, 447, 450, 458) and G.C.A., C2/1/1/174, A meeting of the committee of the heritors and burgesses upon the police bill business, held on the 19 Day of February 1790.

67. This is explored more fully in Barrie (2008, Chapter 3 ).

68. In England, up to the 1820s, it was common for commissioners to be appointed from prominent and affluent local citizens who, in effect, became 'a sort of self-elected substitute corporation.' Fraser (1976, p. 91). See also Langford (1991, pp. 234-236); Webb, Webb (1963, p. 36). 69. Bell, Paton (1896, p. 113).

70. Between 1800 and 1815, a number of Scottish burghs acquired police powers and established elected commissions similar to the Glasgow model. See Greenock, 1801 (41 George III, cap. 51); Port Glasgow, 1803 (43 George III, cap. 121); Edinburgh, 1805 (45 George III, cap. 21); Leith, 1806 (46 George III, cap. 36); Paisley, 1806 (46 George III, cap. 116); Inverness, 1808 (48 George III, cap. 41); Gorbals, 1808 (48 George III, cap. 42); Kilmarnock, 1810 (50 George III, cap. 68); Perth, 1811 (51 George III, cap. 34); Dumfries, 1811 (51 George III, cap. 146); Kirkcaldy, 1811 (51 George III, cap. 35); and Dunfermline, 1811 (51 George III, cap. 61).

71. G.C.A., Glasgow Chamber of Commerce minute book, TD1670/1/1, 17 December 1783.

72. Ibid.

73. The debate over the best way to deal with smuggling lasted between 1783 and 1785 . See, for instance, Ibid., and 2 February 1785.

74. In 1794, for instance, magistrates and councillors in the city thanked Patrick Colquhoun, Justice of the Peace for the County of Middlesex, for his attention in transmitting to the Lord Provost his pamphlet entitled Observations and facts relative to licensed ale houses. G.C.A., C1/1/41, Glasgow town council minute book, 16 October 1794.

75. Dinsmor (2000, p. 9).

76. Colquhoun (1796, passim).

77. Cited in Critchley (1967, p. 39).

78. Colquhoun (1800). 
79. For the influence of the Scottish Enlightenment on the criminal justice system in the second half of the eighteenth century, see Kilday (2007, pp. 31-32).

80. Meek, Raphael, Stein (eds) (1978 edition, p. 332).

81. Ibid. (p. 333).

82. Robertson (1985, passim).

83. Cited in Meek, Raphael, Stein (eds) (1978, p. 332).

84. MacCormick (1982, p. 150).

85. Ibid. (p. 160).

86. Herman (2002, p. 85). Historians of the eighteenth-century criminal justice system in England have also recognised that law was 'concerned with upholding a radical division of property.' Douglas Hay has argued that the eighteenth-century English criminal law was one of the "chief ideological instruments' of the ruling class. Hay (1975, pp. 26, 35, 48). For a critique, see Langbein (1983, pp.102, 119) and King (2000, passim).

87. Cited in Herman (2002, pp. 81-82).

88. Cited in Lieberman (1983, p. 214). Kames (1758, pp. 72-75).

89. Robertson (1983, p.153).

90. MacCormick (1998, p.197).

91. Cited in Ibid. (p. 255).

92. Cited in Ibid. (p. 250).

93. Smith (1761), passim. Smith's views are examined in Skinner (1977).

94. Cited in Herman (2002, p. 184).

95. Skinner (1977, p. 202). See also Smith (1761, VII, iv, 36).

96. See Cairns (1995) and James Miller, Lectures on government (Glasgow, 1787-1788), volumes 1 to 3, Glasgow University library, special collections, MS Gen. 289.

97. Colquhoun (1796, p.v.).

98. Harris (2003, p. 21).

99. Hume (1739 (ed.) Mossmer, 1969, pp. 590-598) and Smith (1761, passim).

100. Ferguson (1767, passim).

101. Radzinowicz (1956, Volume 3, p. 227).

102. Dodsworth (2007, p. 452).

103. Skinner (1977, p. 217).

104. Colquhoun (1814).

105. Robertson (1985, p. 213).

106. Colquhoun (1796, p. 348).

107. Philips, Storch (1999, p. 31).

108. See Palmer (1988, pp. 69-70).

109. Smith (first published in 1776; edited by E. Cannan (1896, p. 422).

110. Reynolds (1998, pp. 89-90).

111. Palmer (1988, passim).

112. G.C.A., T-TH1/1/8, Trades house minutes, 5 April 1790. 


\section{ABSTRACTS}

Patrick Colquhoun's role in pioneering police reform in London has been widely documented. This paper seeks to examine from where his ideas and inspiration on law enforcement were derived. While it is recognised that Colquhoun drew and built upon the works of other police reformers and police models, it is argued that underlying many of his ideas were developments in policing which were taking place in his native Glasgow in the late eighteenth century - ideas, which in turn, were influenced by the intellectual and philosophical revolution known as the Scottish Enlightenment. In exploring this issue, the article will also examine the significant role played by the wider intellectual, commercial and political climate in shaping police reform in Scotland's largest city.

Le rôle pionnier de Patrick Colquhoun dans la réforme de la police londonienne a été largement démontré. Cet article vise à examiner l'origine de son inspiration et de ses idées sur la police. Il est admis que Colquhoun s'est appuyé sur le travail d'autres réformateurs de la police et sur d'autres modèles policiers, mais l'auteur argumente qu'une bonne partie de ses idées provenaient des innovations policières en cours à Glasgow, sa ville natale, à la fin du XVIII ${ }^{\mathrm{e}}$ siècle. Ces innovations étaient elles-mêmes influencées par la révolution philosophique et intellectuelle des Lumières écossaises. Au passage, cet article retrace également le rôle significatif qu'a joué le climat intellectuel, commercial et politique dans la manière dont s'est effectuée la réforme policière dans la principale ville d'Écosse.

\section{AUTHOR}

\section{DAVID G. BARRIE}

School of Humanities, Faculty of Arts, Humanities and Social Sciences, University of Western Australia, 35 Stirling Highway, CRAWLEY WA 6009, dgbarrie@arts.uwa.edu.au David Barrie is a lecturer in British History at the University of Western Australia. He is author of Police in the age of improvement: police development and the civic tradition, 1775-1865, Devon, Willan Publishing, 2008; Epoch-making beginnings to lingering death: the struggle for control of the Glasgow police commission, 1833-46, Scottish historical review, volume LXXXVI, 2, No. 222, October 2007, Edinburgh University Press, pp. 253-277; and Urban order in Georgian Dundee, c.1770-1820, in MacKean, C.A., Harris, B. (eds), History of Dundee, 1500-1800, Dundee, Dundee University Press, 2008. He is currently researching the workings and significance of police courts in nineteenthcentury Scotland. 